\section{DIGITAL COMMONS \\ @ UNIVERSITY OF SOUTH FLORIDA}

\section{ABO: Interactive Journal for Women in the Arts, 1640-1830}

Volume 4

Issue 1 Volume 4.1 (Spring 2014)

Article 10

2014

\title{
Review of Bonnie Latimer, Making Gender, Culture, and the Self in the Fiction of Samuel Richardson: The Novel Individual
}

\author{
Karen Lipsedge \\ Kingston University, k.lipsedge@kingston.ac.uk
}

Follow this and additional works at: https://digitalcommons.usf.edu/abo

Part of the Dramatic Literature, Criticism and Theory Commons, Educational Methods Commons, Feminist, Gender, and Sexuality Studies Commons, and the Literature in English, British Isles Commons

\section{Recommended Citation}

Lipsedge, Karen (2014) "Review of Bonnie Latimer, Making Gender, Culture, and the Self in the Fiction of Samuel Richardson: The Novel Individual," ABO: Interactive Journal for Women in the Arts, 1640-1830: Vol.4: Iss.1, Article 10. http://dx.doi.org/10.5038/2157-7129.4.1.5

Available at: https://digitalcommons.usf.edu/abo/vol4/iss1/10

This Reviews is brought to you for free and open access by Digital Commons @ University of South Florida. It has been accepted for inclusion in ABO: Interactive Journal for Women in the Arts, 1640-1830 by an authorized administrator of Digital Commons @ University of South Florida. For more information, please contact digitalcommons@usf.edu. 


\title{
Review of Bonnie Latimer, Making Gender, Culture, and the Self in the Fiction of Samuel Richardson: The Novel Individual
}

\begin{abstract}
Latimer's Making Gender, Culture, and the Self in the Fiction of Samuel Richardson answers a need in eighteenth-century Richardsonian studies. It is also a thoughtful and long overdue study, which deserves praise and attention. Latimer provides the reader with a greater understanding of the notion of female individuality in Richardson's novels, and also of eighteenth-century culture and contemporary literature. Her research is gratifying in its level of detail, and she is deft in showing correspondences between eighteenth-century culture, fiction and Richardson's novels. Although Sir Charles Grandison lies at the heart of this study, Latimer is equally skilful in devoting attention to Richardson's last novel without marginalizing his other work. In addition, Latimer offers a refreshing and fitting conclusion to Making Gender, Culture, and the Self in the Fiction of Samuel Richardson. By ending with an Afterword, Latimer ensures that she opens out and extends the discussion on the female individual, Richardson's novels and his literary legacy. In Making Gender, Culture, and the Self in the Fiction of Samuel Richardson Latimer suggests that further examination of these areas is not only timely, but also necessary and rewarding.
\end{abstract}

\section{Keywords}

Richardsonian studies, Sir Charles Grandison, eighteenth-century fiction and culture, the eighteenthcentury female individual

\section{Creative Commons License}

(c) $($ ) $\ominus$

This work is licensed under a Creative Commons Attribution-No Derivative Works 3.0 License. 
Bonnie Latimer. Making Gender, Culture, and the Self in the Fiction of Samuel Richardson: The Novel Individual. VT: Ashgate, 2013. Xi + 209pp. Index. ISBN: 97814094463.

Reviewed by Karen Lipsedge

Kingston University, England

Bonnie Latimer's Making Gender, Culture, and the Self in the Fiction of Samuel Richardson answers a need in eighteenth-century Richardsonian studies. Edited collections such as Magaret Anne Doody and Peter Sabor's Samuel Richardson: Tercentenary Essays (1989), Valerie Grosvenor Myer's Samuel Richardson: Passion and Prudence (1986) and Albert Rivero's New Essays on Samuel Richardson (1996), provide authoritative critical readings of Richardson's novels, his biography and literary achievement. Meanwhile Nancy Armstrong's Desire and Domestic Fiction (1987), Tassie Gwilliam's Samuel Richardson's Fictions of Gender (1993) and E. J. Clery's The Feminization Debate in Eighteenth-Century England (2004), identify a synergy between the rise of the eighteenth-century novel and the modern individual and regard Richardson as the novelist most readily associated with the fictional representation of this new individual. In addition, some studies have explored beyond Pamela and Clarissa and devoted attention to Richardson's third novel, Sir Charles Grandison; most notably Gerald Barker's Grandison's Heirs: The Paragon's Progress in the Late EighteenthCentury Novel (1985). However, Latimer's Making Gender is the only recent study to bring Sir Charles Grandison out of the shadows of Richardson's first and second novels so effectively. Moreover, it is one of the few studies to use Sir Charles Grandison as the basis for reassessing Richardson's earlier novels, his role in the construction of female individuality in the mid-eighteenth century, and his influence on later novelists of the period. In her rich and detailed work, Latimer uses Sir Charles Grandison as a stepping stone with which to consolidate literary, social, cultural and intellectual approaches to studying Richardson's oeuvre, the mid-eighteenth-century gendered self and contemporary novels. Consequently, Latimer's Making Gender would be a valuable source for scholars of Richardson, eighteenth-century culture and literature, and gender studies.

Through a comprehensive and meticulous reassessment of cultural, literary and intellectual debates of the period, in Making Gender Latimer locates the construction of the female individuality within the context of mid-eighteenth-century novels, Richardson's novelistic canon and contemporary culture. As Latimer argues convincingly,

Richardson's fictions are instrumental in a cultural shift according to which women became imaginable as individuals [...]. In his novels, Richardson rewrites the vocabularies of gender encountered in a variety of earlier genres and discourses, which generally do not allow for understanding women as individuals. The emphasis on female 'individuality' becomes most evident in Sir Charles Grandison and provides a handle for reading Richardson's work anew, challenging critical certainties. (Latimer 3). 
Accordingly, over the course of five chapters Latimer organizes her book elegantly around areas of the modern individual; reason and understanding; virtue; religious morality; and female freedom and agency, to provide an "examination of Richardson's heroines in light of the qualities essential to eighteenth-century "individuality" (Latimer 3).

In Chapter 1, for instance, Latimer establishes how an appreciation of what constitutes the "individual" and "individuality" in the eighteenth century is crucial for reading Richardson's novels and their relationship to the wider cultural and historical contexts. To examine the meaning of the "individual," Latimer takes an interesting and imaginative approach and draws on examples of satirical and amatory literature to demonstrate how Richardson's heroines are written in reaction to contemporary assumptions that "femininity [..is] antithetical to individuality" (Latimer 10). What results is a fascinating and revelatory rereading of mid-eighteenth-century notions of femininity and the gendered individual. In addition, Latimer provides insight into the process by which Richardson worked against contemporary expectations and norms to construct fictional heroines who represent "distinctly novel individuals" (Latimer 10). Chapter 1 also reveals two strategies that become staples of subsequent chapters in Making Gender. Firstly, in her detailed critical analyses of Richardson's novels, Latimer does not devote more attention to Sir Charles Grandison than to Pamela and Clarissa. Instead, she reconsiders each of these novels "through the lens of Grandison" (Latimer 3). As a result, Latimer reveals the new light that can be shed on all of Richardson's works when his third novel is not marginalized. Secondly, Latimer further enriches and enhances her examinations of Richardson's novels through a comparative analysis of well-known and lesser known sources such as Penelope Aubin's The Life of Charlotta Du Pont (1723) and Eliza Haywood's Fantomina (1725). Consequently, on reading this and subsequent chapters readers acquire a greater understanding of Richardson's novels, as well as their relationship to and influence on eighteenth-century culture and literature.

As a study that interrogates two areas central to eighteenth-century studies-the individual and the novel-it is inevitable that much ground needs to be covered in Making Gender. Nevertheless, Latimer marshals authoritatively and effectively the myriad of often complex and, at times contradictory, literary, cultural and intellectual debates. Furthermore, Latimer's comprehensive knowledge lends a depth and breadth to her analyses of Richardson's novelistic canon, resulting in a rich and textured study that provides new insight into Richardsonian studies, and also eighteenth-century literature and culture. Some of the most interesting Chapters such as Chapter 3, are also the most complicated, however. Consequently, they are likely to unnerve those scholars less familiar with eighteenth-century literature in particular, and eighteenth-century studies in general. There are also some areas in Latimer's Making Gender that would have benefitted from further development. To my mind, one of these is domesticity; a topic that is raised initially in Chapter 1 and then picked up again at intervals throughout the book. In light of the centrality of domesticity in Richardson's novels, however, I would suggest that this subject warranted a more thorough examination. 
These concerns and suggestions aside, Latimer's Making Gender, Culture, and the Self in the Fiction of Samuel Richardson is a thoughtful and long overdue study, which deserves praise and attention. It gives Sir Charles Grandison the considered and detailed critical attention it deserves. In addition, it provides the reader with a greater understanding of the notion of female individuality in Richardson's novels, and also of eighteenth-century culture and literature. Latimer's research is gratifying in its level of detail, and she is deft in showing correspondences between eighteenth-century culture, fiction and Richardson's novels. Although Sir Charles Grandison lies at the heart of this study, Latimer is equally skilful in devoting attention to Richardson's last novel without overshadowing his other work. Latimer also offers a refreshing and fitting conclusion to Making Gender. By ending with an Afterword, Latimer ensures that she opens out and extends the discussion on the female individual, Richardson's novels and his literary legacy. In Making Gender, Culture, and the Self in the Fiction of Samuel Richardson Latimer suggests that further examination of these areas is not only timely, but also necessary and rewarding. 